The Economic Consequences of IFRS adoption: Evidence from New Zealand

\author{
Muhammad Nurul Houqe \\ School of Accounting \& Commercial Law \\ Victoria Business School \\ Victoria University of Wellington \\ Reza M. Monem \\ Griffith Business School \\ Griffith University \\ \& \\ Tony van Zijl \\ School of Accounting \& Commercial Law \\ Victoria Business School \\ Victoria University of Wellington
}

Current Draft: 15.04.13

\title{
Acknowledgements
}

*We thank Mike Bradbury, Fawzi Laswad, Jill Hooks and Asheq Rahman, Grant Richardson, Bryan Howieson, Max Bessell for their helpful comments on earlier versions of the paper. The authors gratefully acknowledge the Victoria Business School, Victoria University of Wellington, for financial support through VUW Summer Scholars Scheme 2011-12 (Grant no 110477). 


\title{
The Economic Consequences of IFRS adoption: Evidence from New Zealand
}

\begin{abstract}
Purpose - The purpose of this paper is to investigate the effect of IFRS adoption on the cost of equity capital in New Zealand listed companies. It is hypothesized that the cost of equity has decreased for New Zealand companies around IFRS adoption due to reduced information asymmetry and improved financial reporting quality.

Design/methodology/approach - We analyze a sample of 354 firm-year observations on New Zealand listed companies over the period 1998-2009. First, we estimate the cost of equity capital by utilizing the modified price-earnings-growth (modified-PEG) ratio model. Then we regress this estimated cost of equity on a set of firm-specific variables known to be correlated with a firm's cost of equity. We also control for year-effects for variation in the underlying risk-free rate (including inflation) across time. The effect of IFRS adoption on cost of equity is captured by a dummy variable.
\end{abstract}

Findings - We find that there is a significant negative association between IFRS adoption and cost of equity capital. We also find that the cost of capital declines for both the mandatory adopters and the voluntary adopters of IFRS. These results are robust to several variations in sample composition and model specification.

Originality/value - This is the first study to provide empirical evidence on the impact of the introduction of IFRS on the cost of capital of New Zealand companies. This study is also motivated by the recent mixed evidence on the adoption of IFRS.

Keywords: Cost of equity capital, IFRS adoption, Economic consequences, New Zealand Paper type: Research paper 


\section{The Economic Consequences of IFRS adoption: Evidence from New Zealand}

\section{Introduction}

This study examines the impact of the introduction of International Financial Reporting Standards (IFRS) on the cost of equity capital of New Zealand (NZ) listed companies. ${ }^{1}$ The introduction of IFRS has many potential benefits. Such benefits include cross-border comparability of financial reports, increased reporting transparency, decreased information costs, reduced information asymmetry and consequent reduction in the cost of capital (Ball, 2006; Horton, Serafeim \& Serafeim, 2008; Leuz \& Verracchia, 2000; DeFond, Hu, Hung \& $\mathrm{Li}, 2010){ }^{2}$ With increasing globalisation, it is becoming more important for entities to present their financial results in a consistent and comparable manner. IFRS provide a uniform set of accounting standards which all entities adopting IFRS must comply with. Around 135 countries now require, permit the use of, or have a policy of convergence with IFRS. These include the European Union, Australia, South Africa, Singapore, Hong Kong, and New Zealand, and it seems certain that the number of countries adopting IFRS will continue to rise during the coming years.

While IFRS have a clear purpose, "to provide information useful in making economic decisions", there has been constant debate on how effective such a set of standards may actually be (IASB, 2001, as cited by Barth, 2008, p.1164). The New Zealand Accounting Standards Review Board approved the adoption of New Zealand equivalents to International Financial Reporting Standards (NZ IFRS) as the mandatory standards under which reporting entities must prepare their financial statements. This was mandatory for accounting periods beginning on or after 1 January 2007 but entities had the option of adopting early from 2005 .

\footnotetext{
${ }^{1}$ Throughout this paper, the term "IFRS" is used to include both the International Accounting Standards (IAS) and the IFRS, unless specific reference is made to particular accounting/reporting standards.

${ }^{2}$ Leuz \& Verracchia (2000) and Horton et al., (2008) have demonstrated, through a test on information asymmetry, that IFRS adoption improves the quality of disclosures, resulting in reduced cost of capital.
} 
There are two schools of thought in the debate on IFRS adoption. Proponents of IFRS argue that by adopting a common set of accounting standards, the comparability of financial statements worldwide should improve facilitating cross-border capital flows and therefore improving liquidity. Also, imposition of the disclosure requirements of IFRS should improve the information quality of companies, particularly those domiciled in countries where lower standards of disclosure were required under national generally accepted accounting principles (GAAP). With reduced information asymmetry, investors are better able to monitor managerial behaviour and thus demand a lower premium for risk. If these arguments hold, mandatory IFRS adoption should have a favourable impact on the cost of equity capital (Lee, Walker and Christensen, 2008, p.5).

The quality of financial reporting is influenced not just by accounting standards but also by firm- and country-level investor protection (Leuz, Dhanajay \& Wysocki, 2003). In a country with strong investor protection, such as New Zealand, strong investor protection is a sufficient condition to provide more comparable and comprehensive information (Hope, Jin \& Kang, 2006). Hence, the incremental investment required by firms in implementing the IFRS would be minimal. This indirectly will increase the net benefit from IFRS adoption.

Although IFRS adoption has been mandatory in New Zealand since 2007 and early adoption was allowed from 2005, companies may differ in their costs of compliance with financial disclosure requirements and the degree to which they are dependent on external financing. "Despite mandatory adoption, companies with little to gain from IFRS may choose to take advantage of entrenched flexibility in IFRS implementation and 'box-tick' their way through the process with a minimum degree of compliance. On the other hand, some companies, with relatively high reliance on the stock market as a source of finance and relatively lower costs of compliance with IFRS disclosure requirements, may choose to 
comply willingly with IFRS" (Lee et al., 2008, p.5). Thus in New Zealand, we would expect to see the greatest impact of IFRS adoption on companies where equity financing dominates.

This is the first study to provide empirical evidence on the impact of the introduction of IFRS on the cost of capital of New Zealand companies. This study is motivated by the recent mixed evidence on the adoption of IFRS. Advocates of IFRS underline their higher quality and an improved comparability while critics of IFRS question their superiority (Barth, Landsman \& Lang, 2008). Moreover, concerns have been raised regarding cross-country studies of IFRS adoption. As Miller (2004) notes, cross-country studies can suffer from limited sample sizes that do not accurately represent a country's corporate sector, display endogeneity of variables at the country level, and may omit strongly correlated variables. Miller (2004) calls for accounting research to be conducted at a country-specific or regionspecific level that would provide a more focused investigation. Miller (2004, p. 266) argues that a "more focused approach would free authors from needing variables available across a wide range of countries, allowing variables to be designed that more cleanly capture the construct being measured". The criticism of the cross-country research approach made by Miller (2004) is one of the key motivations for us to conduct our research at a countryspecific level. This study is also motivated by prior research highlighting that "the benefits of IFRS adoption may come from other sources such as the enhanced comparability of financial statements of NZ companies with those in other parts of the world, lower cost of capital, and the global understanding of reporting under IFRS" (Kabir, Laswad \& Islam, 2010, p. 355).

Using a sample of 354 firm-year observations on New Zealand listed companies over the period 1998-2009, we find that there is a significant negative association between IFRS adoption and the cost of equity capital. We also find that the cost of equity declined both for mandatory and voluntary adopters of IFRS. The results highlight the importance of IFRS 
adoption as a vehicle by which New Zealand has been able to make its capital markets more attractive to foreign investors.

The rest of the paper is organized as follows. Section 2 begins with estimation of the ex-ante cost of equity capital. Section 3 sets out the theoretical framework and hypotheses development. Section 4 describes the research design. Section 5 reports the sample selection procedure and the results of the study, including a number of sensitivity tests. Section 6 provides the conclusion.

\section{Estimating the cost of equity capital}

To estimate the cost of equity capital, we utilize the modified price-earnings-growth (modified-PEG) ratio model as proposed by Easton (2004). The modification of the standard PEG ratio model involves the inclusion of one-year-ahead forecast dividend per share in the model. Botosan \& Plumlee $(2005)^{3}$ conclude that the estimates from the modified-PEG ratio model provides the best measure of the cost of equity capital in a strong investor protection country like the USA because it dominates the other alternatives in the sense that it is consistently and predictably related to various risk measures such as information risk, leverage risk, residual risk, market risk, and growth. Thus, given that New Zealand has strong investor protection, we use the modified-PEG ratio model as stated below:

$$
K_{e}=\left(e p s_{t+2}-e p s_{t+1}+K_{e} * D i v_{t+1}\right) / P_{t}
$$

where $K_{e}$ is the cost of equity capital, eps $s_{t+1}$ is the one-year ahead forecast earnings per share, $e p s_{t+2}$ is the two-year ahead forecast earnings per share, Div $v_{t+1}$ is the one year ahead forecast dividend, and $P_{t}$ is the fiscal year-end price per share.

\section{Theoretical Framework and Hypotheses development}

\footnotetext{
3 Botosan and Plumlee (2005) also report that the dividend discount method, introduced in Botosan and Plumlee (2002), is another appropriate measure of the ex ante cost of equity capital. However, the necessary data is not available for New Zealand companies.
} 
Firms which voluntarily adopted IFRS prior to mandatory adoption are likely to have made the adoption decision based on a cost-benefit analysis (Kirvogorsky, Chang \& Black, 2010). These voluntary adopters thus provide a basis for testing the benefits of IFRS adoption. The International Accounting Standards Board (IASB) stated that IFRS provide "a set of high quality accounting standards that will enhance the consistency, comparability and efficiency of financial statements, enabling global markets to move with less friction" (Kirvogorsky et al., 2010, p. 3). Kirvogorsky et al., (2010) note that there is a high cost associated with the adoption of IFRS. Bradbury \& van Zijl (2006) suggest that firm size is an important driver for IFRS adoption. This is due to larger firms having greater ability to absorb the costs of adoption and because the advantages of IFRS adoption would outweigh the disadvantages. Several studies (e.g., Dumontier \& Raffournier, 1998; Affes \& Callimaci, 2007) have observed a positive relationship between firm size and early IFRS adoption. While the initial cost of implementing IFRS could be significant in terms of staff training and IT support, the conversion could ultimately result in a reduction in the costs of capital and financial reporting (IASB, 2011). It is therefore appropriate to distinguish between firms on the basis of size in investigating the effect of IFRS adoption.

"IFRS adoption has resulted in winners and losers. Rather than portraying IFRS as a uniformly good thing or a uniformly bad thing, it is important to recognize that some firms gain and some firms lose from complex, mandatory accounting changes such as IFRS" (Christensen, Lee \& Walker, 2008, p. 375). Trying to determine any general view on what the economic impacts of adopting IFRS is near impossible, because there are so many variations and subtleties within different firms, industries and countries. Further, country-level implementation of IFRS has the potential to redistribute wealth within the country through differential impacts on the cost of capital (Christensen et al., 2008). 
Florou \& Kosi (2009, p.35) argue that "IFRS can bring benefits to firms and capital providers through improved information quality and enhanced information comparability". Specifically, it is expected that the cost of capital will be reduced after the adoption of IFRS. This is because it is likely that there will be greater transparency and comparability of financial information available to those considering providing capital to a firm. This transparency allows better judgments to be made about the firm; in particular, prospective investors can more accurately assess the risk of providing capital. In most cases this would result in a lower estimate of risk and therefore a lower premium being applied in providing capital (Li, 2010).

The reduced cost of capital is probably the most significant impact of IFRS adoption documented in the literature. This is expected as risk is a large factor in the capital market. Capital market participants will have more trust in corporate reporting, when the quality of accounting information is higher, and therefore, will demand lower premium for risk in capital market transactions. Shi \& Kim (2007) argue that the IFRS adopters benefit from greater and better disclosures via IFRS by having a lower cost of raising capital from equity markets.

However, Florou \& Kosi (2009, p.34-35) place a caveat on this reduced cost of capital when they say "IFRS has positive economic consequences ... but only if the country institutions are strong." Hail, Leuz \& Wysocki (2010, p.386) state that IFRS, due to the "high-quality and more comparable corporate reporting practices", leads to "greater market liquidity, a lower cost of capital, and a better allocation of capital". The greater market liquidity is corroborated by Daske, Hail, Leuz \& Verdi (2008, p.1085) when they say that "market liquidity increases around the time of the introduction of IFRS". Within the European Union, Chiapello \& Medjad (2008) put this down to increased efficiency within the 
member economies, due to the greater comparability of financial information across the member countries.

"As a result of the interdependence between accounting standards and the country's institutional setting and firms' incentives, the economic consequences of changing accounting systems may vary across countries" (Horton et al., 2008, p. 676). Although the literature is not able to measure precisely what the economic impact of adopting IFRS is, there is a broad consensus that firm-, industry- and country-specific factors have a strong role in determining the economic impacts of adopting IFRS. The higher the quality and the more comparable accounting standards are, the greater should be the net economic gain.

Based on these arguments, we propose the following research hypothesis:

\section{Hypothesis 1: Cost of equity capital of New Zealand companies is negatively associated with IFRS adoption.}

Literature in this area separates the effect of IFRS adoption based on whether the adoption of IFRS is voluntary or mandatory. Christensen et al., (2008) argue that firms which voluntarily adopted the IFRS prior to 2005 in Europe did so because they perceived net benefits from such compliance. Christensen, Lee \& Walker, (2007, p. 375-376) point out that "if all UK firms would have benefited from a regime like IFRS then it would have been adopted by the Accounting Standards Board (ASB) years ago." Voluntary adopters see a net gain in adopting IFRS, whereas those who wait until adoption is mandatory either do not expect that they will benefit from adopting IFRS or they are averse to change. Daske et al., (2008, p.1085) state, "Comparing mandatory and voluntary adopters, we find that the capital market effects are most pronounced for firms that voluntarily switch to IFRS, both in the year when they switch and again later, when IFRS become mandatory. While the former result is likely due to self-selection, the latter result cautions us to attribute the capital-market effects for mandatory adopters solely or even primarily to the IFRS mandate." 
Thus we propose the following additional hypothesis:

Hypothesis 2: Voluntary adopters of IFRS in New Zealand experienced larger decline in the cost of equity capital than mandatory adopters.

\section{Research design}

To test the effect of IFRS adoption on the cost of equity capital of New Zealand listed companies, we adopt the following regression equation which includes a set of firm-specific controls for other factors that may affect a firm's cost of equity capital.

$$
\begin{aligned}
& K_{\text {eit }} \quad=\beta_{0}+\beta_{1} \text { IFRS }_{i t}+\beta_{2} \text { LnAssets }_{i t}+\beta_{3} M B_{i t}+\beta_{4} \text { Beta }_{i t}+\text { Year Effects } \\
& \text { where: } \\
& K_{\text {eit }} \quad=\text { is the cost of equity capital for firm } i \text { in year } t \text {. } \\
& I F R S_{i t}=\text { dichotomous variable }=1 \text { where the financial statements are prepared in } \\
& \text { accordance with IFRS and otherwise } 0 \text { for firm } i \text { in year } t \text {. } \\
& \text { LnAssets }_{i t} \quad=\text { natural log of current year total assets for firm } i \text { in year } t \text {. } \\
& M B_{i t} \quad=\text { the ratio of the market value of equity to the book value of equity for firm } \\
& i \text { in year } t \text {. } \\
& \text { Beta = the systematic risk of firm } i \text { in year } t \text {. } \\
& \text { Year effects }=\text { a vector of dummy variables indicating year. }
\end{aligned}
$$

The set of control variables included in Equation (2) have been identified in the prior literature as being relevant to a firm's cost of equity capital. LnAssets is included as a proxy for firm size (measured as the natural log of current year total assets) is included because larger firms have been found to have a lower cost of equity capital, possibly due to lower perceived risk (Botosan \& Plumlee, 2005, Bachoo, Tan \& Wilson, 2013). Market to book ratio $(M B)$ is a proxy for firm growth and is expected to have a negative relationship with the cost of equity capital. Systematic risk (Beta) is also included in the model following from prior literature (Botosan \& Plumlee, 2002, Francis et al., 2004, Azizkhani, Monroe \& Shailer, 2010, Artiach \& Clarkson, 2011). From the CAPM, beta is expected to 
have a positive relation with cost of equity capital while year dummies control for variation in the underlying risk-free rate (including inflation) across time.

We estimate the model both for the full set of firms and for the voluntary adopters.

\section{Sample selection and results}

Data of the sample firms were collected from the World Scope and $\mathrm{I} / \mathrm{B} / \mathrm{E} / \mathrm{S}^{4}$ database for the period 1998-2009. The sample consists of companies listed on the the New Zealand Stock Exchange (NZX) or the New Zealand Alternative Market (NZAX). Our sample selection proceeded as follows. First, we excluded mutual funds, financial companies, overseas companies, companies that prepare their financial statements using foreign GAAP, or use foreign currencies, or where accounting standards could not be determined. Second, companies were excluded if there was no analyst following for one and two years ahead or if there was missing data. Finally, we truncated our sample at $1^{\text {st }}$ and $99^{\text {th }}$ percentiles of the distribution of estimated cost of equity capital. This resulted in a final sample that contains 354 observations on 59 industrial firms.

Table 1 Panel A summarises the sample selection procedure. Panel B reports the sample firms by year and the type of accounting standards applied (NZ IFRS vs. Pre IFRS NZ GAAP). Panel C reports the distribution of sample firms by industry sector. The largest concentration of observations is in the Consumer sector with 53 firm-years followed by Intermediate Durables sector with 45 firm-years. On the other hand, Food (6 firm-years) and Textiles \& Apparel (7 firm-years) have the lowest number of observations. The sample of 354 observations contained 123 observations related to voluntary adopters.

\section{[Insert Table 1]}

\footnotetext{
${ }^{4}$ Data on the sample firms were collected from the World Scope data base (http://www.worldscope.com) held at the School of Accounting and Business Information Systems, Australia National University, Canberra, Australia.
} 
Panel A of Table 2 provides descriptive statistics on the cost of equity capital and on all the independent variables. It is evident that the sample firms experienced a lower cost of capital after IFRS adoption. The mean cost of equity capital for the entire sample is 0.0985 . Firm size (LnAssets) shows considerable variation with a mean of 5.57 and standard deviation of 0.611. The market to book ratio $(M B)$ and Beta have the means of 1.59 and 1.01, respectively. Panel B of Table 2 shows that the cost of equity capital declined after the IFRS adoption as the correlation of cost of capital with IFRS adoption is negative $(r=-0.201)$ and significant $(p$-value $=0.049)$.

\section{[Insert Table 2]}

\subsection{Main analysis}

Table 3 shows the results of estimation of the regression equation both for the full set of firms and the subset of firms which voluntarily adopted the IFRS (VIFRS firms). It is evident that switching from Pre-IFRS NZ GAAP to NZ IFRS resulted in a lower cost of equity capital. The cost of equity capital decreased for both the full set of firms and the subset of VIFRS firms. Surprisingly, the decrease in the cost of equity was similar across the full set and the subset, as we had expected that the decrease would be larger for the subset of voluntary adopters. However the absence of the expected result may be due to many of the voluntary adopters merely following their parent company based in a compulsory IFRS adopting country.

Among the control variables, LnAssets has a negative significant coefficient (two tailed $p$-value $<0.10$ ) in the regression for the full set as well as the regression for the VIFRS firms. The market to book ratio, $M B$ ratio, is significant in both sets and has a negative impact on the cost of capital. As expected, systematic risk (Beta) is significant and positive 
for both sets of firms, that is, the higher the systematic risk the higher the cost of equity capital.

\section{[Insert Table 3]}

\subsection{Robustness tests ${ }^{5}$}

\subsubsection{Alternative measure of cost of capital}

The Capital Asset Pricing Model (CAPM) is widely used to calculate the cost of equity capital. The CAPM takes into account the asset's sensitivity to market risk which is represented by the equity beta as well as the expected return of the market and the risk free rate of return. From the equity beta, investors can understand that a portfolio of high-beta stocks will move more than the market, and a portfolio of low-beta stocks will move less than the market. Although the CAPM is not a perfect model, it provides a useful measurement of risk that helps to determine the cost of equity capital. To estimate the cost of equity capital under the CAPM, we applied the post-investor tax specification of the CAPM using the following formula and inputs:

$R_{e}=R_{f}\left(1-T_{i}\right)+b_{e}\left[R_{m}-D_{m} T_{m}-R_{f}\left(1-T_{i}\right)\right]$

where:

$R_{f}=$ the risk free rate of return based on the NZ Government Bond yield.

$T_{i}=$ investor's effective tax rate on interest and dividend income and capital gains. Because some investors are subject to capital gains tax in New Zealand, $T_{i}$ is not equal to the marginal personal income rate.

$b_{e}$ - Equity Beta - Equity Beta estimates used in calculating WACC are based on an average of monthly returns over (up to) five years. The equity beta estimates incorporate a minimum asset beta of 0.3 .

$\left[R_{m}-D_{m} T_{m}-R_{f}\left(1-T_{i}\right)\right]=$ Post-Investor-Tax Market Risk Premium, where:

$D_{m}=$ the cash dividend yield on the market portfolio.

\footnotetext{
${ }^{5}$ The results are available from the corresponding author on request.
} 
$T_{m}=$ tax parameter applicable to the market dividend yield.

We derived our estimate of the post-investor-tax market risk premium from PricewaterhouseCoopers $(\mathrm{PwC})$ research on New Zealand equity market returns.

We re-estimated Equation (2) for voluntary and mandatory IFRS adopters by using PwC-published cost of capital data (2004-2012). A Pearson's correlation test between the sample firms which adopted IFRS and the cost of capital measured by PwC over this period confirms a negative and significant relation between the two variables $(r=-0.196, p$-value $=$ 0.037). The results (not reported) show that IFRS adoption is associated with lower cost of capital in the full set (coefficient of IFRS $=-0.0010, p$-value $=0.061$ ) and even more so for the voluntary adopters (coefficient of IFRS $=-0.0013, p$-value $=0.059$ ).

\subsubsection{Alternative measure of economic consequences}

We re-estimated Equation (2) for both sets of firms using Tobin's Q as an alternative proxy for the economic consequences of IFRS adoption in New Zealand. The (untabulated) results show that IFRS adoption is associated with higher performance in the full set (coefficient of IFRS $=1.352, p<0.01$ ) and even more so for the voluntary adopters (coefficient of IFRS = 1.998, $p<0.01)$.

\subsubsection{Excluding bottom quartile $K_{e}$ firms}

Dhaliwal et al., (2009) note that firms with a low cost of equity capital are less likely to benefit from a switch to higher quality reporting. We therefore re-estimated Equation (2) using a sample which excluded the bottom quartile of firms with the lowest cost of equity capital. The results (not reported) show a higher model fit for both sets of firms but no difference in the association with IFRS adoption.

\section{Conclusions}

This study contributes to the debate on the benefits of IFRS adoption by examining the economic consequence of IFRS adoption as indicated by a decrease in the cost of capital of 
New Zealand listed companies. Using a sample of 354 firm-year observations over the period 1998-2009, we find a significant negative association between IFRS adoption and the cost of equity. The results are robust to variations in sample composition and model specification. Furthermore, our results are consistent with Daske et al., (2008), Armstrong, Barth, Jagolinzer \& Riedl (2010), Li (2010), and Palea (2010).

We acknowledge that this study is subject to limitations. First, our sample size is relatively small, which reflects the small size of the NZ corporate sector. Second, as is common in empirical research, the results are subject to possible bias as a result of omitted unknown but relevant variables. Nevertheless, our study provides the first piece of evidence of the impact of IFRS adoption on the cost of equity of New Zealand firms. 


\section{References}

Affes, H., \& Callimaci, A. (2007). The determinants of the early adoption of international accounting standards: Financial decision or opportunism? Comptabilite Controle Audit, 13(2), 149-163.

Armstrong, C., Barth, M., Jagolinzer, A., \& Riedl, E. (2010). Market Reaction to the Adoption of IFRS in Europe. The Accounting Review, 85 (1), 31-61.

Azizkhani, M., Monroe, G. S. and Shailer, G. (2010). Auditor Tenure and Perceived Credibility of Financial Reporting. Accounting \& Finance, 50(4), 743-766.

Bachoo, K., Tan, R., \& Wilson, M. (2013). Firm value and the Quality of Sustainability Reporting in Australia. Australian Accounting Review, 23(1), 67-87.

Ball, R. (2006). International Financial Reporting Standards (IFRS): pros and cons for investors. Accounting and Business Research, 36 (special issue), 5-27.

Barth, M. E. (2008). Global Financial Reporting: Implications for U.S. Academics. The Accounting Review, 83 (5), 1159-1179.

Barth, M. E., Landsman W. R., \& Lang, M. H. (2008). International Accounting Standards and Accounting Quality. Journal of Accounting Research, 46 (3), 467-498.

Botosan, C. A., \& Plumlee, M. A. (2002). A re-examination of disclosure level and the expected cost of equity capital. Journal of Accounting Research, 40 (1), 21-40.

Botosan, C. A., \& Plumlee, M. A. (2005). Assessing alternative proxies for the expected risk premium. The Accounting Review, 80 (1), 21-53.

Bradbury, M., \& van Zijl, T. (2006). Due Process and the Adoption of IFRS in New Zealand. Australian Accounting Review, 16 (39), 86-94.

Chiapello, E., \& Medjad, K. (2008). An unprecedented privatisation of mandatory standardsetting: The case of European accounting policy, Critical Perspectives on Accounting, 20 (4), 448-468.

Christensen, H. B., Lee, E., \& Walker, M. (2007). Cross-sectional variation in the economic consequences of international accounting harmonization: The case of mandatory IFRS adoption in the UK. The International Journal of Accounting, 42 (4), 341-379.

Christensen, H. B., Lee, E. \& Walker, M. (2008). Incentives or Standards: What Determines Accounting Quality Changes Around IFRS Adoption? AAA 2008 Financial Accounting and Reporting Section (FARS) Paper, retrieved from http://ssrn.com/abstract=1013054.

Daske, H., Hail, L., Leuz, C. and Verdi, A. (2008). Mandatory IFRS Reporting around the World: Early Evidence on the Economic Consequences. Journal of Accounting Research, 46 (5), 1085-1142.

DeFond, M. L., Hu, X., Hung, M., \& Li, S. (2010). The Impact of Mandatory IFRS Adoption on Foreign Mutual Fund Ownership: The Role of Comparability. SCU Leavey School of Business Research Paper No. 09-06, USA.

Dhaliwal, D. S., Li, O. Z., Tsang, A. H., and Yang, Y. G. (2009). Voluntary non-financial disclosure and the cost of equity capital: The case of corporate social responsibility reporting. Working paper, available at SSRN: http://ssrn.com/abstract=1343453.

Dumontier, P., \& Raffournier, B. (1998). Why Companies Comply Voluntarily with IAS: An Empirical Analysis with Swiss Data. Journal of International Financial Management and Accounting, 9 (3), 216-245.

Easton, P. D. (2004). PE ratios, PEG ratios, and estimating the implied expected rate of return on equity capital. The Accounting Review, 79 (1), 73-94. 
Florou, A., \& Kosi, U. (2009). The Economic Consequences of Mandatory IFRS Adoption for Debt Financing. Working paper, retrieved from http://ssrn.com/abstract=1508324.

Gebhardt, W., Lee, C., \& Swaminathan, B. (2001). Toward an implied cost of capital. Journal of Accounting Research, 39 (1), 135-176.

Hail, L., Leuz, C., \& Wysocki, P. (2010). Global accounting convergence and the potential adoption of IFRS by the U.S. (part I): Conceptual underpinnings and economic analysis. Accounting Horizons, 24 (3), 355-394.

Hope, O-K., Jin, J., and Kang, T. (2006). Empirical Evidence on Jurisdictions that Adopt IFRS. Journal of International Accounting Research, 5(2), 1-20.

Horton, J., Serafeim, G., \& Serafeim, I. (2008). Does Mandatory IFRS Adoption Improve the Information Environment? Harvard Business School Working Paper No. 1264101, Harvard Business School, Massachusetts, USA, available at http://ssrn.com/abstract=1264101.

IASB. (2001).International Accounting Standards Board, retrieved from: http://www.iasb.org/home.

IASB. (2011). International Accounting Standards Board, retrieved from: http://www.iasb.org/home

Kabir, M. H., Laswad, F., \& Islam, M. A. (2010). Impact of IFRS in New Zealand on Accounts and Earnings Quality. The Australian Accounting Review, 55(4), 343-357.

Kirvogorsky, V., Chang, J., \& Black, E. (2010). Analysis of Corporate Characteristics Motivating Companies to Early Adopt IFRS: Evidence from the European Union. Working paper, retrieved from http://ssrn.com/abstract=1488336.

Lee, E., Walker, M., \& Christensen, H. B. (2008). Mandating IFRS: its Impact on the Cost of Equity Capital in Europe. Research Report 105, ACCA, UK.

Li. S. (2010). Does Mandatory Adoption of International Financial Reporting Standards in the European Union Reduce the Cost of Equity Capital? The Accounting Review, 85 (2), 607-636.

Leuz, C., \& Verracchia, R. E. (2000).The Economic Consequences of Increased Disclosure. Journal of Accounting Research, 38 (3), 91-124.

Leuz, G., Dhanajay, N., \& Wysocki, P. (2003). Earnings Management and Investor Protection: an international comparison. Journal of Financial Economics, 69 (3), 505527.

Miller, G. S. (2004). Discussion of What Determines Corporate Transparency. Journal of Accounting Research, 42(2), 253-268.

Modigliani, F., \& Miller, M. (1958). The expected cost of equity capital, corporation finance, and the theory of investment. American Economic Review, 48 (3), 261-297.

Palea, V. (2010). The Effects on the IAS/IFRS Adoption in the European Union on the Financial Industry. Working paper, University of Turin, retrieved from http://ssrn.com/abstract=1088712.

PWC (Price Waterhouse Coopers). The Cost of Capital Report, 2004-2012. Available at http://www.pwc.co.nz/appreciating-value/edition-three/

Shi, S. \& Kim, J-B. V. (2007). International Financial Reporting Standards, Institutional Infrastructures and Costs of Equity Capital around the World. Working paper, available at http://ssrn.com/abstract=984127.

World Scope data base. (2010). Available at http://www.worldscope.com. 


\section{Table 1}

Panel A: Sample selection procedure

Firms

Firm-years

Firms covered by World scope and I/B/E/S database

144

-Financial institutions, funds, overseas companies

38

-Firms whose financial statements were prepared using foreign

4

GAAP

-Firms whose financial statements are using foreign currency

-Firms whose accounting standards could not be determined

1

(46)

98

-Firm-years with missing data

(39)

Study sample

59

$\underline{354}$

Panel B: Sample by year and GAAP

\begin{tabular}{cccc}
\hline Year & All firms & IFRS & Pre IFRS NZGAAP \\
\hline 1998 & 13 & - & 13 \\
1999 & 15 & - & 15 \\
2000 & 19 & - & 19 \\
2001 & 20 & - & 20 \\
2002 & 20 & - & 20 \\
2003 & 24 & - & 24 \\
2004 & 28 & - & 28 \\
2005 & 30 & 02 & 28 \\
2006 & 40 & 15 & 25 \\
2007 & 47 & 26 & 21 \\
2008 & 52 & 52 & 0 \\
2009 & 46 & 46 & 0 \\
Total & $\mathbf{3 5 4}$ & $\mathbf{1 4 1}$ & $\mathbf{2 1 3}$ \\
\hline
\end{tabular}

Panel C: Sample firm year observations by industries

\begin{tabular}{lccc}
\hline Industries & Sample firms & Firm years & $\%$ \\
\hline Agriculture \& Fishing & 5 & 29 & 8.2 \\
Building Materials \& Construction & 3 & 24 & 6.8 \\
Consumer & 8 & 53 & 15.0 \\
Energy / Energy Processing & 4 & 31 & 8.8 \\
Food & 2 & 6 & 1.7 \\
Intermediate durables & 6 & 45 & 12.7 \\
Investment & 2 & 13 & 3.7 \\
Leisure \& Tourism & 2 & 21 & 5.9 \\
Media \& Communications & 3 & 15 & 4.2 \\
Mining & 1 & 2 & 0.6 \\
Other services & 9 & 42 & 11.9 \\
Ports & 4 & 26 & 7.3 \\
Property & 5 & 15 & 4.2 \\
Textiles \& apparels & 1 & 7 & 2.0 \\
Transport & 3 & 25 & 7.1 \\
Total & $\mathbf{5 9}$ & $\mathbf{3 5 4}$ & $\mathbf{1 0 0}$ \\
\hline
\end{tabular}


Table 2

Panel A: Descriptive statistics - control variables

\begin{tabular}{|c|c|c|c|c|c|c|c|c|c|c|}
\hline \multirow{2}{*}{$\begin{array}{l}\text { Variables } \\
\text { Variables }\end{array}$} & \multicolumn{4}{|c|}{ All firms year } & \multicolumn{2}{|c|}{ IFRS firm-years } & \multicolumn{3}{|c|}{ Non-IFRS firm-years } & \multirow{2}{*}{$\begin{array}{l}t \text {-statistics } \\
\text { for } \\
\text { difference } \\
\text { in means }\end{array}$} \\
\hline & $\mathrm{n}$ & Mean & S.D. & $\mathrm{n}$ & Mean & S.D. & $\mathrm{n}$ & Mean & S.D. & \\
\hline$\overline{K_{e}}$ & 354 & 0.0985 & 0.02140 & 141 & 0.0845 & 0.01425 & 213 & 0.1015 & 0.01642 & $18.231^{\text {*** }}$ \\
\hline IFRS & 354 & 0.4000 & 0.49000 & 141 & & & & & & \\
\hline Ln Assets & 354 & 5.5651 & 0.61074 & 141 & 5.6065 & 0.60844 & 213 & 5.5755 & 0.59968 & -0.432 \\
\hline$M B$ & 354 & 1.7927 & 2.08541 & 141 & 1.9370 & 1.44893 & 213 & 1.6904 & 2.10452 & $6.109^{* * *}$ \\
\hline Beta & 354 & 1.0120 & 0.55622 & 141 & 0.9578 & 0.55493 & 213 & 1.0599 & 0.56881 & 1.564 \\
\hline
\end{tabular}

$K_{e}$ is the cost of equity of firm $i$ in year $t$ measured by modified-PEG model (Easton, 2004). IFRS takes the value of 1 if the firms prepare their financial statement under IFRS, and 0 otherwise. Ln Assets is the log of total assets of firm $i$ in year $t . M B$ is the market to book ratio of firm $i$ in year $t$. Beta is a measure of systematic risk which shows the relationship between the volatility of the stock and the volatility of the market. This coefficient is based on between 23 and 35 consecutive month end price percent changes and their relativity to a local market index.

${ }^{* * * * *}$ and ${ }^{*}$ indicate significance at the $1 \%, 5 \%$ and $10 \%$ levels, respectively.

Panel B: Correlation analysis

\begin{tabular}{|c|c|c|c|c|c|}
\hline Variables & $K_{e}$ & IFRS & Ln Assets & $M B$ & Beta \\
\hline \multicolumn{6}{|l|}{$K_{e}$} \\
\hline & 1 & & & & \\
\hline \multirow[t]{2}{*}{ IFRS } & $-0.201^{* *}$ & & & & \\
\hline & $(0.049)$ & 1 & & & \\
\hline \multirow[t]{2}{*}{ Ln Assets } & -0.004 & 0.055 & & & \\
\hline & $(0.127)$ & $(0.301)$ & 1 & & \\
\hline \multirow[t]{2}{*}{$M B$} & $-0.185^{* * *}$ & $-0.325^{* * *}$ & $-0.341^{* * * *}$ & 1 & \\
\hline & $(0.002)$ & $(0.000)$ & $(0.000)$ & & \\
\hline \multirow[t]{2}{*}{ Beta } & $0.192^{* * *}$ & -0.079 & $0.008^{* * * *}$ & $-0.132^{* *}$ & \\
\hline & $(0.001)$ & $(0.136)$ & $(0.887)$ & $(0.032)$ & 1 \\
\hline
\end{tabular}

Note: $p$-values are in parenthesis.

$K_{e}$ is the cost of equity of firm $i$ in year $t$ measured by modified-PEG model (Easton, 2004). IFRS takes the value of 1 if the firms prepare their financial statement under IFRS, and 0 otherwise. Ln Assets is the log of total assets of firm $i$ in year $t . M B$ is the market to book ratio of firm $i$ in year $t$. Beta is a measure of systematic risk which shows the relationship between the volatility of the stock and the volatility of the market. This coefficient is based on between 23 and 35 consecutive month end price percent changes and their relativity to a local market index.

${ }^{* * * * * *}$ and ${ }^{*}$ indicate significance at the $1 \%, 5 \%$ and $10 \%$ levels, respectively. 


\section{Table 3}

Results of multivariate regressions of cost of equity capital $\left(K_{e i t}\right)$ on IFRS adoption and other determinants

$\boldsymbol{K}_{\text {eit }}=\beta_{0}+\beta_{1}$ IFRS $_{i t}+\beta_{2}$ LnAssets $_{i t}+\beta_{3} M B_{i t}+\beta_{4}$ Beta $_{i t}+$ Year Effects...

\begin{tabular}{|c|c|c|c|c|}
\hline \multirow[t]{2}{*}{ Regressor } & \multicolumn{2}{|c|}{ All firms year } & \multicolumn{2}{|c|}{ VIFRS firms year } \\
\hline & Coeff. & VIF & Coeff. & $V I F$ \\
\hline \multirow[t]{2}{*}{ Intercept } & $0.1041^{* * * *}$ & & $0.1054^{\text {***** }}$ & \\
\hline & $(0.000)$ & & $(0.000)$ & \\
\hline \multirow[t]{2}{*}{ IFRS } & $-0.0011^{* * *}$ & 1.9798 & $-0.0014^{* *}$ & 1.9012 \\
\hline & $(0.043)$ & & $(0.040)$ & \\
\hline \multirow{2}{*}{ Ln Assets } & $-0.0026^{*}$ & 1.6015 & $-0.0029^{*}$ & 1.3012 \\
\hline & $(0.090)$ & & $(0.071)$ & \\
\hline \multirow[t]{2}{*}{$M B$} & $-0.0068^{* * * *}$ & 1.5214 & $-0.0076^{* * *}$ & 1.6478 \\
\hline & $(0.000)$ & & $(0.000)$ & \\
\hline \multirow[t]{2}{*}{ Beta } & $0.0062^{* * * *}$ & 1.3874 & $0.0065^{* * *}$ & 1.4014 \\
\hline & $(0.006)$ & & $(0.008)$ & \\
\hline Year Effects & \multicolumn{2}{|c|}{ Yes } & \multicolumn{2}{|c|}{ Yes } \\
\hline$N$ & \multicolumn{2}{|c|}{354} & \multicolumn{2}{|c|}{123} \\
\hline Adjusted $R^{2}$ & \multicolumn{2}{|c|}{0.282} & \multicolumn{2}{|c|}{0.297} \\
\hline$f$-Stat & & & \multicolumn{2}{|c|}{$58.141^{* * * *}$} \\
\hline
\end{tabular}

Note: p-values are in parenthesis.

$K_{e}$ is the cost of equity of firm $i$ in year $t$ measured by modified-PEG model (Easton, 2004). IFRS takes the value of 1 if the firms prepare their financial statement under IFRS, and 0 otherwise. VIFRS takes the value of 1 if the firms prepare their financial statement under IFRS after 2005, and 0 otherwise Ln Assets is the log of total assets of firm $i$ in year $t . M B$ is the market to book ratio of firm $i$ in year $t$. Beta is a measure of systematic risk which shows the relationship between the volatility of the stock and the volatility of the market. This coefficient is based on between 23 and 35 consecutive month end price percent changes and their relativity to a local market index. Year effects, a vector of dummy variables indicating year.

${ }^{* * *},{ }^{* *}$ and ${ }^{*}$ indicate significance at the $1 \%, 5 \%$ and $10 \%$ levels, respectively. 